\title{
PERANCANGAN STRATEGIS SI/TI PADA DINAS PERTAMBANGAN DAN ENERGI PROVINSI NTT MENGGUNAKAN FRAMEWORK WARD DAN PEPPARD
}

\author{
Olivia Maria Inacio Tavares ${ }^{1}$, Ema Utami ${ }^{2}$, Hanif Al Fatta ${ }^{3}$ \\ ${ }^{123}$ Program Studi Magister Teknik Informatika, Universitas AMIKOM Yogyakarta \\ Jln. Ring Road Utara, Ngringin Condongcatur, Sleman, Yogyakarta, Indonesia (55281) \\ lolivia.1280@students.amikom.ac.id, ${ }^{2}$ ema.u@amikom.ac.id, ${ }^{3}$ hanif.a@amikom.ac.id.
}

\begin{abstract}
Abstrak - Pemanfaatan SI/TI telah menjadi faktor utama penentu keunggulan kompetitif bagi setiap instansi. Diketahui masih terdapat banyak kekurangan dalam pemanfaatan SI/TI pada Dinas Pertambangan dan Energi Provinsi NTT, yakni belum ada integrasi sistem diantara setiap bidang kerja pada dinas, dimana sistem yang dibangun menggunakan basis data terpisah sehingga mengakibatkan implementasi SI/TI tidak berjalan secara maksimal, banyaknya kegiatan operasional yang berjalan secara manual sehingga mengakibatkan lambatnya proses pelayanan publik, hal ini dikarenakan belum adanya susunan rencana strategis yang sesuai dengan kebutuhan dinas. Melihat kondisi tersebut melalui penelitian ini akan dilakukan analisa perencanaan strategis SI/TI dengan memanfaatkan Framework Ward dan Peppard dalam menganalisis lingkungan bisnis dan lingkungan internal-eksternal SI/TI pada dinas. Rancangan yang dihasilkan mencakup analisa SWOT, Value Chain, PEST, Five Force Model serta McFarland Strategic Grid. Hasil penelitian ini berupa rekomendasi portofolio SI/TI yang diharapkan mampu memudahkan kegiatan operasional serta meningkatkan keunggulan kompetitif pada dinas dengan instansi serupa lainnya.
\end{abstract}

Kata Kunci_- Perencanaan Strategis SI/TI, Framework Ward dan Peppard, Keunggulan Kompetitif, Portofolio SI/TI.

Abstract - The utilization of IS/IT has become the main factor to determine the competitive advantage in every agency. It is known there is still many shortcomings in the use of IS/IT at the Mining and Energy Office of NTT Province, including there is no system integration between each work field in the agency, where the system is built using a separate database, which effecting the IS/IT implementation not running optimally, a lot of operational activities run manually resulting in the slow process of public services, this is due to the absence of a strategic plan arrangement that is in accordance with the needs of the service. Seeing these conditions, this research will analyze the IS/IT strategic design by using Ward and Peppard Framework to analyze the business environment and the internal-external IS/IT environment at the agency. The layot includes a SWOT analysis, Value Chain, PEST, Five Force Model and McFarland Strategic Grid. The results of this study are in the form of IS/IT portofolio recommendations which are expected to facilitate the operational activities and increase competitive advantage in the agency with the other similar agencies.

Keywords - IS/IT Strategic Plan, Ward and Peppard Framework, Competitive Advantage, IS/IT Portofolio.

\section{PENDAHULUAN}

Penerapan sistem informasi dan teknologi informasi (SI/TI) saat ini telah menjadi tolak ukur utama yang mempengaruhi keberhasilan proses bisnis dalam suatu perusahaan ataupun instansi, hal ini berbanding lurus seiring dengan perkembangan kebutuhan setiap individu dalam dunia industri yang kian hari terus meningkat[1]. Adanya perencanaan tata kelola teknologi informasi sangatlah dibutuhkan dalam menunjang setiap kegiatan fungsional dan operasional pada sebuah organisasi (IT Governance) mulai dari penyusunan model rencana strategi (RENSTRA), implementasi strategis, monitoring serta evaluasi terhadap pengembangan kerangka sistem informasi dan teknologi yang tengah diterapkan[2].
Memiliki strategi bisnis yang umum dan tidak ditelaah secara baik sesuai visi, misi serta tujuan instansi dapat menyebabkan ketidakmampuan dalam menghadapi persaingan bisnis[3]. Menanggapi hal tersebut maka dibutuhkanlah suatu strategi untuk mendukung keunggulan kompetitif dengan perusahaan kompetitor lainnya. Sudah sewajarnya bagi setiap perusahaan mulai menganalisa kerangka strategi yang paling tepat digunakan untuk mengembangkan keunggulan operasionalnya[4]. Setiap instansi dituntut untuk dapat merumuskan perencanaan strategi dengan memanfaatkan SI/TI, guna meningkatkan efisiensi proses bisnis yang berjalan, seperti pada proses pengolahan data, peningkatan kualitas layanan kepada stakeholder, solusi dalam pengambilan keputusan serta membantu mewujudkan visi, misi dan tujuan bisnis 
instansi terkait yang dapat mendukung kesuksesan implementasi bisnis di masa yang akan datang[5].

Berdasarkan susunan peraturan untuk kinerja sistem kepemerintahan di Negara Kesatuan Republik Indonesia yang diatur dalam (Undang-Undang Nomor.5 Tahun 2014) tertulis bahwa kinerja dinas yang terbaik harus mampu mencerminkan kualitas pemerintahan yang semakin maju dan berkembang dengan berbagai kemudahan dalam melaksanakan aktivitas dan tanggung jawabnya, dimana dalam hal ini dapat dengan cepat dan tepat mengambil keputusan untuk memajukan kinerjanya[6].

Salah satu instansi pemerintah yang membutuhkan analisa perencanaan strategis SI/TI yaitu Dinas Pertambangan dan Energi Provinsi NTT yang bergerak dalam 4 bidang yakni Bidang Energi Baru-terbarukan, lalu Bidang Mineral dan Batubara, Bidang Ketenagalistrikan, serta Bidang Geologi dan Air Tanah.

Berdasarkan hasil observasi dan wawancara, diketahui penerapan SI/TI pada dinas tersebut masih memiliki banyak kekurangan dilihat dari belum adanya sistem yang terintegrasi diantara tiap bidang sehingga memperlambat alur kegiatan operasional dan fungsional yang seharusnya dapat dijalankan dengan lebih efisien dan efektif.

Kendala lainnya yaitu masih dibutuhkan pembenahan sumber daya manusia yang berkompeten dalam bidang SI/TI, dimana sebagian besar aparatur masih belum memahami penggunaan teknologi maupun sistem informasi dengan baik, selain itu lambatnya proses pelayanan kepada pihak masyarakat (public service) terutama dalam pendistribusian bantuan pemasangan listrik tenaga surya (PLTS).

Oleh karena sistem yang digunakan masih berjalan secara konvensional salah satunya untuk pengiriman proposal, dimana pihak desa diharuskan untuk mengantar atau mengirimkan melalui kantor pos, selanjutnya progress pemasangan diinformasikan oleh aparatur melalui telepon hal tersebut tentu memakan banyak waktu dan biaya. Pihak dinas juga sering melewatkan pemasangan bantuan listrik pada beberapa desa yang membutuhkan hingga mengakibatkan terjadinya duplikasi pengiriman proposal disebabkan oleh pihak dinas yang tak kunjung menanggapi.

Meski saat ini Distamben Provinsi NTT tengah merencanakan perbaikan SI/TI namun perbaikan tersebut belum didukung dengan adanya perencanaan strategis yang memadai, oleh karena itu implementasi SI/TI pada dinas belum bisa dikatakan maksimal. Berdasarkan hal tersebut maka dibutuhkanlah sebuah model kerangka perencanaan strategis sistem informasi dan teknologi yang dapat menjadi acuan pembenahan SI/TI bagi dinas di masa mendatang.

Agar mampu menyusun model perencanaan strategis SI/TI yang tepat dan sesuai dengan kebutuhan dari instansi maka dibutuhkanlah suatu kerangka kerja atau framework khusus yang dapat digunakan sebagai metode atau teknik untuk mendukung proses pemetaan blueprint portofolio perancangan strategis SI/TI yang membantu mengatasi permasalahan-permasalahan serta meningkatkan keunggulan kompetitif. Berdasarkan uraian kendala yang dihadapi pada dinas maka peneliti mengusulkan untuk memanfaatkan kerangka kerja (Framework) Ward dan Peppard.

Pemilihan framework tersebut didasarkan oleh karena framework ini memiliki lebih banyak kelebihan jika dibandingkan dengan kerangka kerja lainnya yang mana framework ini memiliki alur analisis yang lengkap dan tidak hanya berfokus pada kondisi SI dan TI namun juga memperhatikan beragam aspek bisnis internal dan eksternal dari lokasi penelitian[7], memiliki kerangka kerja yang fleksibel dan mudah dimengerti serta dapat di implementasi dalam perencanaan strategis SI/TI secara menyeluruh[8]. Selain itu dalam penelitian[9] yang dilakukan oleh Prasetyo telah dibuktikan bahwa pemanfaatan Framework Ward dan Peppard mampu memberikan hasil rekomendasi strategi SI/TI yang mendukung peningkatan kinerja proses bisnis dari perusahaan yang menjadi objek penelitiannya dikarenakan tahapan analisis dilakukan dengan meneliti proses bisnis internal dan eksternal sehingga hasil yang diperoleh menjadi lebih maksimal dari berbagai sudut pandang.

Terdapat beberapa penelitian terdahulu yang dijadikan sebagai pembanding serta rujukan dalam menganalisa perencanaan strategis SI/TI bagi Dinas Pertambangan dan Energi Provisi NTT diantaranya yaitu Analisis perencanaan strategis di Dinas Energi dan Sumber Daya Mineral (ESDM) Kabupaten Kuantan Singingi[10] yang memberikan saran perbaikan melalui IT Roadmap dengan memetakan prioritas pengembangan piranti SI/TI berdasarkan hasil analisis SWOT. Penelitian serupa juga dilakukan dalam[11] menggunakan Framework Zachman dalam menyusun pemetaan arsitektur strategis sistem. Dari kedua penelitian ini terdapat beberapa kekurangan yaitu tidak adanya tahap implementasi sistem sehingga tidak diketahui perbandingan sistem yang lama dengan sistem baru yang diusulkan, selain itu dalam Penelitian Penerapan Zachman Framework pada arsitektur sistem penggajian[12] mendefinisikan Framework Zachman memiliki kerangka yang jauh lebih rumit untuk diimplementasikan secara keseluruhan. Oleh karenanya dibutuhkanlah model framework yang lebih tepat dan fleksibel untuk digunakan dalam menganalisa perencanaan strategis SI/TI pada instansi kepemerintahan yaitu Framework Ward dan Peppard.

Selanjutnya penelitian[13] dilakukan oleh Kasma yang meneliti perencanaan strategis SI untuk meningkatkan persaingan kompetitif dengan memanfaatkan Framework Ward dan Peppard, alur penelitian ini dimulai dari memahami situasi eksternal dan internal lingkungan saat ini, baik lingkungan bisnis dan SI/TI. Metode analisis yang digunakan adalah Value Chain, SWOT, dan McFarland Strategic Grid. Hasil penelitian kemudian menunjukkan bahwa organisasi membutuhkan perencanaan strategis SI/TI agar dapat bersaing dengan para kompetitornya. 
Penelitian lainnya yaitu Perencanaan strategis dengan menggunakan Framework Ward dan Peppard[14] penelitian ini memanfaatkan model analisa Value Chain, SWOT, CFS dan McFarland Strategic Grid, hasil yang didapatkan yaitu berupa Page | 174 portofolio usulan aplikasi sesuai kebutuhan instansi.

Pada keempat penelitian terdahulu model metode analisis yang digunakan hanya mencakup 3 hingga 4 model analisa umum dengan hasil akhir analisa dipetakan dalam bentuk roadmap usulan pengembangan SI/TI. Sedangkan analisis lainnya seperti Five Forces Competitive dan PEST belum banyak digunakan serta tidak dipetakan perbandingan atau keuntungan yang dihasilkan dari implementasi sistem lama dengan usulan SI/TI terbaru sehingga terkesan memberikan solusi usulan tanpa hasil pembaharuan yang jelas mengenai kekurangan maupun hal-hal penting yang perlu diperbaharui dari sistem telah yang ada.

Berdasarkan latar belakang permasalahan pada Dinas Pertambangan dan Energi Provinsi NTT maka sebagai suatu bentuk solusi, peneliti mengusulkan untuk menyusun sebuah penelitian yang berjudul "Perancangan Strategis SI/TI Pada Dinas Pertambangan Dan Energi Provinsi NTT Menggunakan Framework Ward dan Peppard" yang akan memberikan model rencana strategis secara mendalam sesuai dengan kebutuhan dinas beserta masterplan SI/TI untuk jangka waktu 5 tahun kedepan.

\section{METODE PENELITIAN}

Konsep untuk metode penelitian ini menggunakan metode kualitatif yang memiliki tujuan untuk menggambarkan serta menganalisa kegiatan-kegiatan operasional maupun fungsional yang dijalankan pada instansi[15]. Adapun metode kualitatif tersebut didapatkan melalui analisa permasalahan yang ditemui berdasarkan hasil studi literatur terhadap data pendukung yang diperoleh di lapangan baik dari hasil telaah laporan maupun hasil wawancara dan observasi.

Metodologi yang digunakan dalam penelitian ini pada dasarnya mengikuti alur kerja Framework Ward dan Peppard seperti pada Gbr. 1. sebagai model kerangka kerja Ward dan Peppard berikut ini[16]:

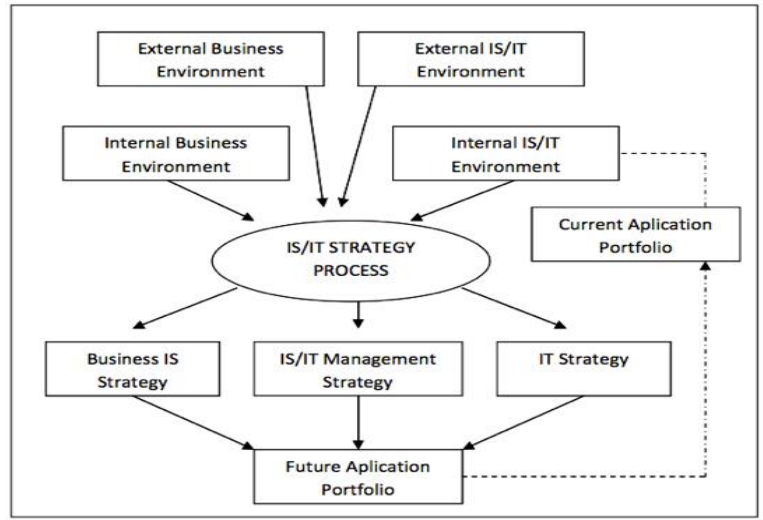

Gbr. 1 Framework Ward dan Peppard
Selain itu, untuk tahapan dari penelitian diurutkan melingkupi beberapa proses yang ditampilkan pada Gbr. 2. berikut:

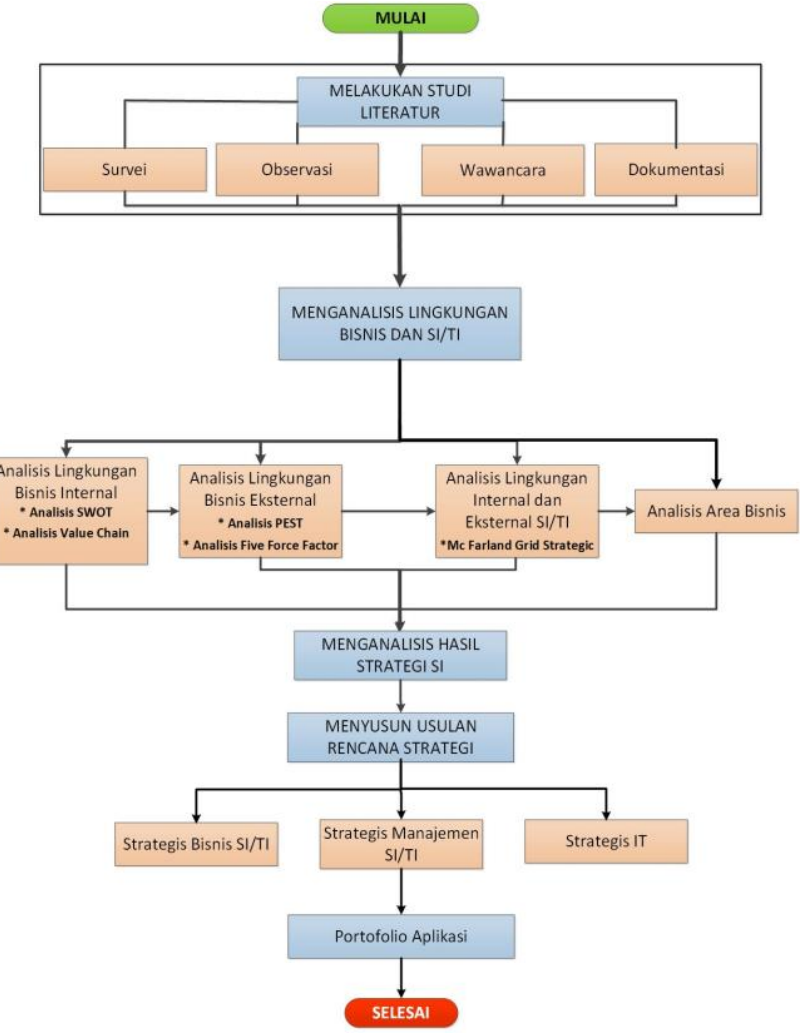

Gbr. 2 Bagan Alur Penelitian

Penelitian ini dijalankan melalui beberapa alur tahapan yang saling berkaitan diantara tahap yang satu dengan tahap lainnya. Berikut penjelasan kegiatan dari setiap tahapan yang ditampilkan pada Gbr.2:

\section{A. Tahapan Awal}

Pada tahapan pertama peneliti melakukan studi literatur dengan mengumpulkan berbagai referensi pendukung sebagai landasan dan kerangka berpikir. Kegiatan ini melalui beberapa tahapan diantaranya:

1) Melakukan Survei: Melalui penyebaran kuesioner bebas terkait proses bisnis serta kendala yang dihadapi pada dinas khususnya pihak aparatur.

2) Melakukan Observasi: Dengan pengamatan secara langsung pada lingkungan dinas untuk mengetahui proses bisnis yang berjalan.

3) Melakukan Wawancara: Dalam tahapan ini peneliti mewawancarai pimpinan (Kepala Dinas), aparatur serta beberapa warga yang pernah terlibat dengan kegiatan bisnis. Wawancara berkaitan dengan piranti SI/TI yang dioperasikan pada dinas.

4) Mengumpulkan Dokumentasi: Dalam tahapan ini dilakukan pengumpulan data pendukung penelitian melalui berbagai sumber laporan, buku serta jurnal terkait perencanaan strategis.

\section{B. Tahapan Kedua}

Pada tahapan kedua peneliti mulai melakukan analisis terhadap lingkungan bisnis serta lingkungan 
SI/TI di Distamben untuk dapat menghasilkan bentuk perencanaan strategis yang paling tepat dan sesuai dengan kebutuhan dinas melalui tahapan diantaranya:

1) Analisis Lingkungan Bisnis Internal: Dalam tahapan ini peneliti melakukan analisis SWOT dan analisis Value Chain berdasarkan data yang telah dikumpulkan pada tahapan awal.

2) Analisis Lingkungan Bisnis Eksternal: Dalam tahapan ini peneliti melakukan analisis PEST dan analisis Five Force Factor pada lingkungan bisnis eksternal dinas.

3) Analisis Lingkungan Internal dan Eksternal SI/TI: Dalam tahapan ini peneliti mulai menganalisis kebutuhan SI/TI pada dinas dan kemudian memetakannya dalam McFarland Strategic dengan kaitannya dalam tren SI/TI saat ini.

4) Analisis Area Bisnis: Dalam tahapan ini peneliti mengidentifikasi peluang bisnis yang perlu mendapatkan perhatian khusus untuk pengembangan, disaat yang sama analisis ini dilakukan untuk mengetahui ancaman bisnis yang perlu diantisipasi oleh pihak dinas.

\section{Tahapan Ketiga}

Dalam tahapan ketiga peneliti mulai menganalisa hasil-hasil rancangan strategis SI/TI yang menjadi kebutuhan utama pada setiap bidang dalam menjalankan proses bisnisnya serta penyelarasan kebutuhan strategi instansi dengan strategi SI/TI dinas.

\section{Tahapan Keempat}

Pada tahapan keempat peneliti menyusun usulan rencana strategi yang mencakup usulan pengembangan strategi bisnis SI/TI, usulan pengembangan strategis manajemen SI/TI serta usulan strategis IT yang dibutuhkan dinas dalam membenahi kinerja fungsional dan operasionalnya untuk meningkatkan keunggulan kompetitif dengan instansi serupa lainnya.

\section{E. Tahap Akhir}

Pada tahapan kelima yang menjadi akhir dari penelitian ini akan ditampilkan hasil berupa pemetaan portofolio usulan untuk peningkatan sistem informasi dan teknologi (SI/TI) bagi Dinas Pertambangan dan Energi Provinsi NTT beserta dengan roadmap rentang waktu rencana implementasinya untuk pengembangan SI/TI beberapa waktu ke depan.

\section{HASIL DAN PEMBAHASAN}

Pembahasan menguraikan hasil analisis terhadap lingkungan bisnis serta lingkungan SI/TI. Analisis yang dihasilkan akan menjadi dasar penentuan usulan akhir untuk mengatasi berbagai permasalahan yang tengah dihadapi instansi serta dapat dijadikan sebagai referensi pengembangan rencana strategis dinas dalam meningkatkan keunggulan kompetitif. Pembahasan analisis ini mencakup beberapa proses sebagai berikut:

\section{A. Analisis Lingkungan Bisnis Internal}

Proses awal yang dilakukan dalam menganalisis lingkungan bisnis internal pada dinas dimulai melalui penerapan analisis SWOT dalam menganalisa kekuatan yang dimiliki instansi (Strength), kelemahan (Weaknesses), peluang (Opportunities), serta ancaman yang dihadapi instansi dalam menjalankan proses bisnisnya (Threats)[17]. Berikut hasil analisis SWOT:

TABEL I

HASIL ANALISIS SWOT

\begin{tabular}{|c|c|}
\hline Strength & Weaknesses \\
\hline 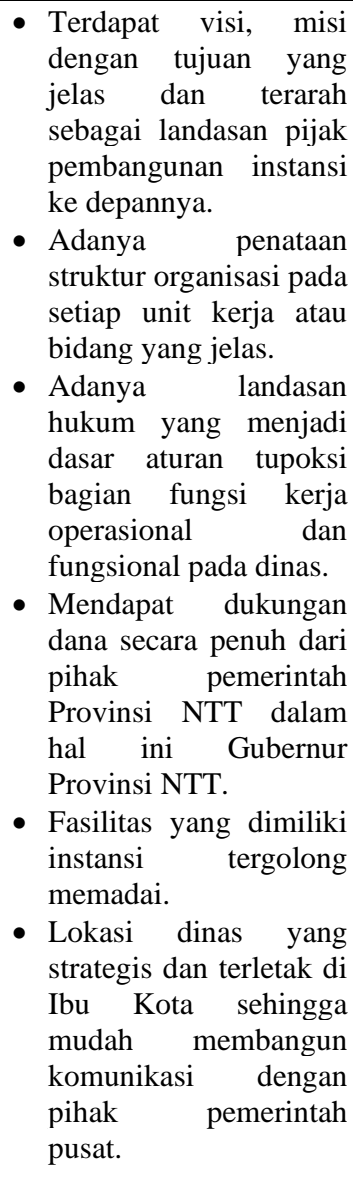 & $\begin{array}{l}\text { - } \text { Kualitas Sumber Daya } \\
\text { Manusia rendah. } \\
\text { - } \text { Belum adanya } \\
\text { pemanfaatan SI/TI yang } \\
\text { terintegrasi diantara } \\
\text { setiap bidang pada dinas } \\
\text { sehingga proses kerja } \\
\text { operasional dan } \\
\text { fungsional masih } \\
\text { tergolong lambat. } \\
\text { - } \text { Tidak adanya } \\
\text { perencanaan jadwal } \\
\text { secara pasti dalam } \\
\text { pendistribusian bantuan } \\
\text { listrik tenaga surya } \\
\text { terutama pada wilayah- } \\
\text { wilayah yang } \\
\text { membutuhkan sehingga } \\
\text { banyak wilayah yang } \\
\text { terlewatkan. } \\
\text { Banyaknya penempatan } \\
\text { aparatur yang tidak } \\
\text { sesuai dengan keahlian } \\
\text { yang dimiliki. } \\
\text { Belum adanya rencana } \\
\text { strategi yang terarah } \\
\text { untuk pengembangan } \\
\text { dinas ke depannya. } \\
\text { Penyusunan laporan } \\
\text { kinerja sering terlambat. } \\
\text { Proses pelayanan publik } \\
\text { yang berbelit-belit. }\end{array}$ \\
\hline Opportunities & Threats \\
\hline 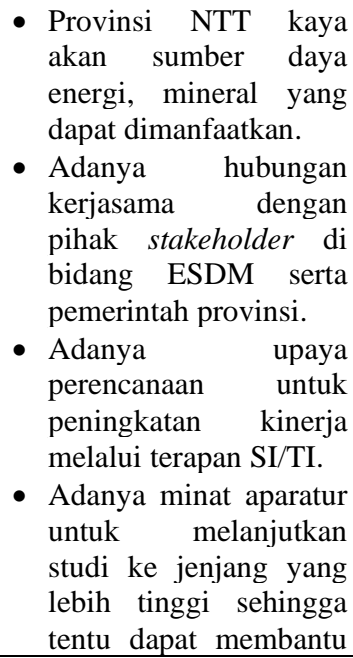 & $\begin{array}{l}\text { - Banyaknya kompetitor } \\
\text { dari pihak swasta dalam } \\
\text { bidang ESDM. } \\
\text { - Penguasaan pangsa pasar } \\
\text { yang masih lemah. } \\
\text { - Sulitnya komunikasi } \\
\text { diantara pihak dinas dan } \\
\text { masyarakat pada masa } \\
\text { pandemi COVID19 } \\
\text { terutama menyangkut } \\
\text { pemasangan listrik } \\
\text { tenaga surya. }\end{array}$ \\
\hline
\end{tabular}




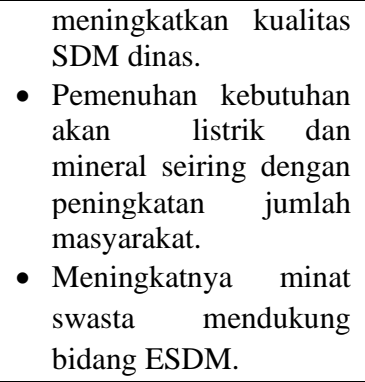

- Meningkatnya minat swasta mendukung bidang ESDM.

Dalam Tabel 1 diuraikan hasil identifikasi macammacam kekuatan (Strength), kelemahan (Weaknesses), peluang (Opportunities), serta ancaman (Threats) yang saat ini dihadapi oleh instansi dalam menjalankan proses bisnisnya. Setelah berhasil diuraikan hasil analisis sesuai yang ditampilkan pada Tabel I, maka dapat dirumuskan ragam upaya pengembangan yang dapat digunakan sebagai poin perencanaan strategis SI/TI pada dinas diantaranya:

1) Strength and Opportunities (SO): Yaitu strategi yang dapat digunakan untuk mengisi peluang yang ada diantaranya yakni a) Dikembangkannya eksplorasi secara intens dalam memanfaatkan potensi pertambangan dan energi yang dimiliki Provinsi NTT, b) Dilakukan peningkatan pembangunan sarana bidang pertambangan dan energi, c) Menyelenggarakan pameran ataupun pengenalan terkait potensi ESDM yang dimiliki sehingga secara tidak langsung dapat memberikan keunggulan tersendiri, d) Meningkatkan hubungan kerjasama dengan pihak stakeholder dan pemerintah, e) Mulai membangun tim kerja untuk merencanakan pembangunan macam piranti SI/TI yang dapat membantu meningkatkan kinerja operasional dan fungsional dinas, f) Menyediakan bantuan dana bagi aparatur yang berkeinginan untuk melanjutkan pendidikan ke jenjang yang lebih tinggi, dan g) Mendukung pemanfaatan SI/TI dalam memudahkan komunikasi dengan pemerintah setempat.

2) Strength and Threats (ST): Yaitu strategi yang dapat digunakan dengan memanfaatkan kekuatan instansi untuk menghindari ancaman yang ada diantarannya yakni a) Memanfaatkan dukungan dari pemerintah untuk menyebarluaskan layanan-layanan terkait pengembangan ESDM kepada masyarakat untuk menarik pangsa pasar, b) Menyediakan fasilitas kontak yang dapat membantu memudahkan proses komunikasi diantara pihak masyarakat dan aparatur dan c) Meningkatkan pengawasan di bidang ESDM.

3) Weaknesses and Opportunities (WO): Yaitu strategi yang dapat digunakan dengan meminimalisir kelemahan untuk meningkatkan peluang yang ada diantaranya a) Mendukung peningkatan kualitas Sumber Daya Manusia (SDM), b) Membangun serta membenahi piranti SI/TI yang digunakan dalam mendukung kegiatan operasional dan fungsional dinas, c) Menyusun penjadwalan untuk setiap kegiatan dinas secara jelas beserta dengan pembagian tupoksi kerja setiap aparatur, d) Membagi tugas aparatur sesuai keahlian yang dimiliki, dan e) Menyusun pedoman dalam perencanaan pengembangan SI/TI bagi dinas.

4) Weaknesses and Threats (WT): Yaitu strategi yang dapat digunakan dengan meminimalisir kelemahan untuk menghindari ancaman yang ada diantaranya a) Melakukan pengembangan SDM, b) Mengembangkan potensi dalam bidang ESDM yang dimiliki Provinsi NTT, c) Merancang dan membangun fasilitas-fasilitas SI/TI penunjang komunikasi dan interaksi internal bagi dinas, serta d) Meningkatkan regulasi atau perijinan perihal pemanfaatan ESDM.

Setelah dilakukan analisis SWOT, langkah selanjutnya yaitu melakukan analisis Value Chain untuk mengetahui proses operasional dan fungsional yang berjalan pada dinas. Dengan dilakukannya analisis Value Chain ini akan diidentifikasi macam kegiatan yang berfokus pada aktivitas utama dan pendukung[18]. Berikut hasil Analisa Value Chain :

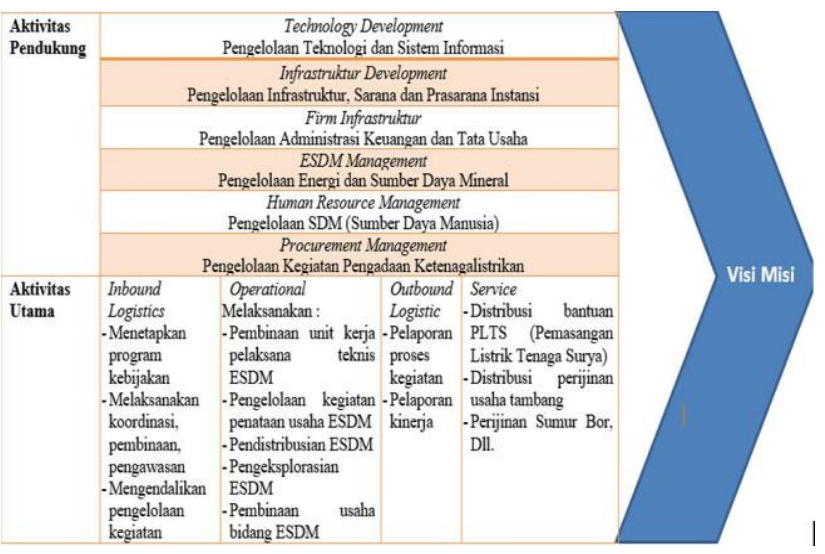

Gbr. 3 Hasil Analisis Value Chain

Gbr 3. menunjukkan hasil analisis Value Chain. Berdasarkan gambaran Value Chain kegiatan pada dinas dibagi ke dalam 2 pembagian aktivitas yaitu aktivitas utama dan aktivitas pendukung. Aktivitas utama yang dilakukan dinas untuk mencapai visi, misi serta tujuan bisnis diantaranya:

1) Menetapkan Program Kebijakan: Penetapan kebijakan dalam pengelolaan ESDM didasarkan pada ketentuan dan peraturan yang telah ditetapkan oleh pemerintah Provinsi NTT.

2) Melaksanakan Koordinasi: Prosedur memulai koordinasi dapat dilakukan melalui pembinaan serta pengawasan dalam pengelolaan bidang ESDM.

3) Mengendalikan Kegiatan Pengelolaan: Dilaksanakan melalui penyusunan persyaratan serta perijinan dalam pengelolaan di bidang ESDM.

4) Mendukung Kegiatan Operasional Dinas: diantaranya a) Pembinaan unit pelaksana teknis SDM, b) Pengelolaan penataan usaha dalam bidang ESDM, serta c) Pengekplorasian usaha ESDM

5) Menyusun Pelaporan Proses Setiap Kegiatan

6) Menyusun Pelaporan Kinerja per-Bulan

7) Kegiatan Terkait dengan Pelayanan Publik: dalam hal ini diantarannya a) Distribusi bantuan PLTS 
(Pemasangan Listrik Tenaga Surya), b) Distribusi perijinan usaha tambang, dan c) Perijinan sumur bor dan bidang ESDM lainnya.

\section{B. Analisis Lingkungan Bisnis Eksternal}

Proses awal tahapan dilakukan dalam menganalisis lingkungan bisnis eksternal pada dinas dimulai melalui penerapan analisis PEST atau (politic, economy, social, technology) dengan mengidentifikasikan lingkungan bisnis eksternal[19]. Analisis ini berfokus pada bidang politik, ekonomi, sosial dan teknologi sebagai berikut:

1) Politics (Politik): Merupakan analisa terhadap faktor politik dalam lingkungan eksternal yang kemudian mempengaruhi perencanaan pembangunan dalam bidang ESDM yaitu, dapat dilihat dari berbagai kebijakan pemerintah baik pemerintah pusat, maupun pemerintah provinsi NTT yang memiliki kaitan dengan sektor ESDM sehingga akan berdampak terhadap pengembangan kedepannya, berupa Peraturan Daerah (PERDA) dan PerundangUndangan negara. Keberhasilan ataupun kegagalan pembangunan ESDM tidak akan terlepas dari landasan politik yang ada. Berdasarkan UndangUndang No.23 Tahun 2014 tentang pemerintah daerah menyatakan sasaran yang perlu dicapai dalam menyusun, mengendalikan serta mengevaluasi perencanaan pembangunan daerah yang dimana menjadi satu kesatuan utuh yang perlu untuk diikutsertakan. Selain itu ada pula ketentuan hukum untuk penyusunan RENSTRA pada dinas diantaranya dalam Undang-Undang No.4 tahun 2009, Peraturan Menteri Negeri No.54 tahun 2010.

2) Economy (Ekonomi): Merupakan analisa terhadap faktor ekonomi dalam lingkungan eksternal yang dimaksudkan disini yaitu berbagai kecenderungan perekonomian di luar sektor ESDM yang dapat memberikan pengaruh baik secara langsung ataupun tidak langsung terhadap perencanaan pembangunan yang tercermin antara lain melalui telaah perkembangan kinerja perekonomian Provinsi NTT. Dalam tahun 2010 hingga 2019 terdapat banyak peningkatan ekonomi yang dapat dilihat diantaranya berdasarkan besaran Produk Domestik Regional Bruto (PDRB) atas dasar harga yang berlaku triwulan ke III tahun 2019 mencapai Rp.27,40 triliun dan atas dasar harga konstan tahun 2010 yang mencapai Rp.17.74 triliun. Dalam hal ini tentu adanya peran utama dari sektor ESDM dengan dilakukan pendistribusian listrik per-kapita yang menjadi salah satu program penting yang diancangkan oleh dinas dengan kaitannya untuk segera meningkatkan kebutuhan perekonomian masyarakatnya. Melihat kondisi tersebut maka pihak dinas harus selalu membenahi program-programnya untuk lebih berperan memajukan kesejahteraaan ekonomi salah satunya yaitu pada bidang ketenagalistrikan yang berdampak terhadap sektorsektor produktif lainnya dalam meningkatkan pendapatan dan kualitas hidup masyarakat bukan hanya sebatas pada sektor penerangan saja.

3) Social (Sosial): Merupakan analisa yang dilakukan dengan melihat dari pengaruh sektor ESDM terhadap kondisi ekonomi yang tentunya berbanding lurus dengan keadaan sosial kemasyarakatan, dimana dengan adanya upaya-upaya pengembangan program dari dinas dalam mendistribusikan akses listrik maupun meningkatkan kebutuhan masyarakat akan kebutuhan dalam bidang energi dan sumber daya mineral tentunya akan meningkatkan standar kehidupan publik mulai dari peningkatan pendapatan, pendidikan serta kesehatan masyarakat luas.

4) Technology (Teknologi): Dilihat dari faktor teknologi yang mempengaruhi lingkungan bisnis eksternal melalui perkembangan teknologi yang kian berkembang di bidang ESDM tentu akan memberikan dampak secara langsung dan tidak langsung terhadap pengelolaan sumber daya alam yang dimiliki Provinsi NTT. Teknologi tersebut contohnya dalam pemetaan wilayah usaha penambangan, teknologi pelayanan publik dalam perijinan bidang ESDM dan lain sebagainya. Melalui peningkatan teknologi tentu mendorong peningkatan kualitas mutu pembangunan dan pengolahan ESDM sehingga dapat meningkatkan PAD daerah terkhusus pada Provinsi NTT. Melihat pengaruh besar teknologi, maka diperlukan adanya perencanaan serta pembangunan model piranti SI/TI baru sesuai dengan kebutuhan setiap bidang pada dinas yang lebih memadai dalam upaya membantu melancarkan operasional serta pelayanan dinas.

Setelah dilakukan analisis PEST selanjutnya dilakukan analisis Five Force Factor untuk mengidentifikasikan posisi eksternal dinas. Analisis dilakukan dengan memetakan berbagai macam kegiatan eksternal kedalam 5 pembagian kekuatan kompetitif[20] sebagai berikut:

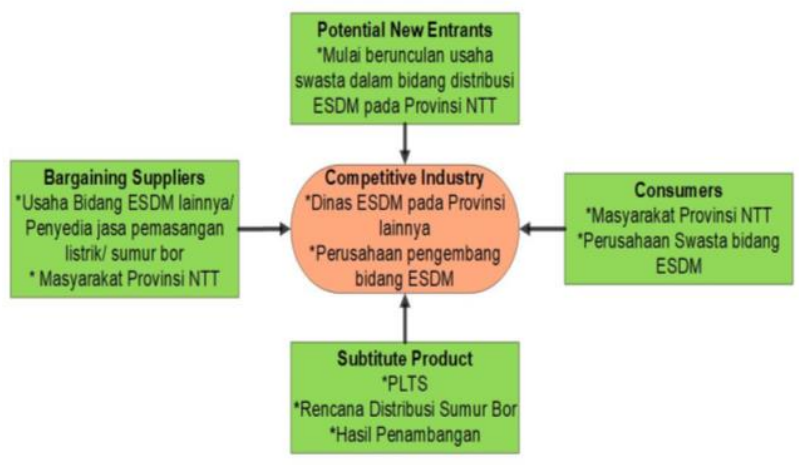

Gbr. 4 Hasil Analisis Five Force Factor

Uraian analisis five force factor diantarannya yakni:

1) Competitive Rivalry Within an Industry: Pesaing utama bisnis organisasi adalah dari Dinas Pertambangan dan Energi pada provinsi atau wilayah lainnya serta perusahaan pengembang dalam bidang ESDM misalkan perusahaan tambang serta 
pengeboran swasta yang saat ini mulai banyak menyebar di Provinsi NTT.

2) Barganing Power of Customers: Public service pada dinas saat ini yaitu kepada pihak masyarakat Provinsi NTT serta perusahaan-perusahaan swasta yang ingin mengajukan perijinan terkait usaha pengembangan dalam bidang ESDM.

3) Bargaining Power of Supplier: Dalam hal ini didapatkan melalui perusahaan bidang ESDM lainnya mulai dari penyedia jasa pemasangan listrik atau sumur bor serta pihak masyarakat.

4) Threats of New Entrants: Dilihat dari mulai bermunculannya perusahaan swasta bidang ESDM pada Provinsi NTT.

5) Subtitute Product: Merupakan macam produk yang dihasilkan dalam proses operasional dan fungsional Dinas Pertambangan dan Energi Provinsi NTT salah satunya dalam bidang ketenagalistrikan ada bantuan pendistribusian PLTS (Pemasangan Listrik Tenaga Surya), sumur bor serta distribusi hasil penambangan.

\section{Analisis Lingkungan Internal-Eksternal SI/TI serta} Area Bisnis pada dinas

Menganalisis lingkungan bisnis internal dan eksternal pada Dinas Pertambangan dan Energi Provinsi NTT dilakukan melalui penerapan analisis McFarland Grid Strategic dengan melihat kondisi SI/TI beserta areal bisnisnya [21]. Berikut ditampilkan daftar implementasi SI/TI beserta kebutuhan dan areal bisnis yang berjalan:

TABEL III

DAFTAR IMPLEMENTASI SI/TI AREA BISNIS DINAS

\begin{tabular}{|c|c|c|c|}
\hline No. & $\begin{array}{c}\text { Kebutuhan } \\
\text { Aktivitas }\end{array}$ & Pengguna & $\begin{array}{c}\text { Nama Piranti } \\
\text { SI/TI }\end{array}$ \\
\hline 1. & $\begin{array}{l}\text { Pengelolaan } \\
\text { SDM \& data } \\
\text { kepegawaian }\end{array}$ & $\begin{array}{c}\text { Subbag Umum } \\
\& \\
\text { Kepegawaian }\end{array}$ & $\begin{array}{r}\text { SIMPEG } \\
\text { ESDM }\end{array}$ \\
\hline 2. & $\begin{array}{l}\text { Pengelolaan } \\
\text { kebutuhan } \\
\text { administrasi } \\
\text { keuangan }\end{array}$ & $\begin{array}{c}\text { Subbag } \\
\text { Administrasi } \\
\text { \& Keuangan }\end{array}$ & $\begin{array}{r}\text { SIKEU } \\
\text { ESDM } \\
\text { (Desktop } \\
\text { Based })\end{array}$ \\
\hline 3. & $\begin{array}{l}\text { Sistem } \\
\text { absensi } \\
\text { Fingerprint } \\
\end{array}$ & $\begin{array}{c}\text { Seluruh } \\
\text { Pegawai Dinas } \\
\text { ESDM } \\
\end{array}$ & Biometrik \\
\hline 4. & $\begin{array}{l}\text { Pengadaan } \\
\text { sarana } \\
\text { prasarana }\end{array}$ & $\begin{array}{c}\text { Subbag Tata } \\
\text { Usaha }\end{array}$ & $\begin{array}{r}\text { EPROC } \\
\text { ESDM }\end{array}$ \\
\hline 5. & $\begin{array}{l}\text { Pengelolaan } \\
\text { kegiatan } \\
\text { distribusi } \\
\text { ESDM }\end{array}$ & $\begin{array}{l}\text { Subbag } \\
\text { Program }\end{array}$ & $\begin{array}{r}\text { SI ESDM } \\
\text { (gatrik.esdm.g } \\
\text { o.id) }\end{array}$ \\
\hline 6. & $\begin{array}{l}\text { Pengelolaan } \\
\text { informasi } \\
\text { promosi, } \\
\text { profil dan } \\
\text { kontak }\end{array}$ & Pusat & $\begin{array}{r}\text { Website } \\
\text { umum Dinas } \\
\text { ESDM } \\
\text { (Psdg.esdm.g } \\
\text { o.id) }\end{array}$ \\
\hline 7. & $\begin{array}{l}\text { Pengelolaan } \\
\text { pelaporan } \\
\text { hasil usaha } \\
\text { tambang }\end{array}$ & $\begin{array}{l}\text { Pengusaha } \\
\text { ESDM }\end{array}$ & SILUP ESDM \\
\hline
\end{tabular}

\begin{tabular}{|c|c|c|c|}
\hline 8. & $\begin{array}{l}\text { Pengawasan } \\
\text { kegiatan } \\
\text { penjualan } \\
\text { batu bara }\end{array}$ & Pusat & $\begin{array}{r}\text { Modul } \\
\text { Verifikasi } \\
\text { Penjualan } \\
\text { (MVP) } \\
\text { Mvp.esdm.go. } \\
\text { id }\end{array}$ \\
\hline 9. & $\begin{array}{l}\text { Pemetaan } \\
\text { wilayah } \\
\text { penambangan } \\
\text { provinsi NTT }\end{array}$ & $\begin{array}{c}\text { Terbagi setiap } \\
\text { kabupaten }\end{array}$ & $\begin{array}{r}\text { Website } \\
\text { umum } \\
\text { penambangan } \\
\text { per-kab }\end{array}$ \\
\hline
\end{tabular}

Setelah diketahui daftar dari macam-macam piranti SI/TI yang diimplementasikan untuk mendukung proses bisnis pada Dinas Pertambangan dan Energi Provinsi NTT, selanjutnya dapat dilakukan pemetaan kriteria dan kebutuhan pengembangan atau pembangunan dari setiap aplikasi yang ada dengan menggunakan analisis McFarland Strategic. Melalui pemanfaatan analisis ini pihak instansi dapat diketahui pembagian prioritas dari setiap piranti sehingga dapat segera dilakukan upaya-upaya pengembangan atau pembangunan untuk memaksimalkan fungsi kerja SI/TI yang digunakan. Berikut dapat ditampilkan hasil dari analisa McFarland Strategic:

TABEL IIIII

HASIL ANALISA MCFARLAND STRATEGIC GRID

\begin{tabular}{|c|c|}
\hline STRATEGIC & HIGH POTENTIAL \\
\hline $\begin{array}{ll}\text { - } & \text { SI ESDM* } \\
\text { - } & \text { Modul Verifikasi } \\
& \text { Penjualan (MVP)* } \\
\text { - } & \text { SILUP ESDM** }\end{array}$ & 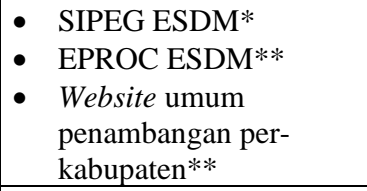 \\
\hline $\begin{array}{ll}\text { - } & \text { SIKEU ESDM* } \\
\text { - } & \text { Sistem } \\
& \text { Fingerprint } * *\end{array}$ & $\begin{array}{l}\text { - Website umum Dinas } \\
\text { ESDM }^{* * *}\end{array}$ \\
\hline KEY OPERATIONAL & SUPPORT \\
\hline $\begin{aligned} \text { Note: } & * \\
& * * \\
& * * *\end{aligned}$ & $\begin{array}{l}\text { Sistem memadai } \\
\text { Sistem perlu diperbaharui } \\
\text { Sistem perlu dibangun }\end{array}$ \\
\hline
\end{tabular}

Dilihat berdasarkan kondisi SI/TI eksternal dan hubungannya dengan tren perkembangan SI/TI saat ini, terdapat banyak instansi kepemerintahan atau organisasi yang telah memanfaatkan penerapan khusus SI/TI mulai dari integrasi jaringan server untuk setiap unit kerja dalam dinas, aplikasi (software) penunjang yang lengkap dan memadai, fasilitas hardware serta pengamanan SI/TI lainya. Banyak manfaat yang dapat dihasilkan apabila mengikuti perencanaan strategis ini kedepannya dengan mengikuti tren perkembangan SI/TI tentu akan memberikan peningkatan kinerja public service, serta memudahkan integrasi komunikasi diantara berbagai pihak.

\section{Menyusun Usulan Rencana Strategis (RENSTRA)}

Dalam penyusunan rencana strategis akan dibagi kedalam 3 model identifikasi yaitu sebagai berikut:

1) Identifikasi Strategis Bisnis SI/TI: Berdasarkan berbagai hasil analisa yang telah 
dilakukan maka dapat ditarik kesimpulan untuk mengidentifikasi bentuk rekomendasi-rekomendasi strategis bisnis yang paling tepat dalam meningkatkan kinerja operasional dan fungsional pada Dinas Pertambangan dan Energi Provinsi NTT serta meningkatkan keunggulan kompetitif, diantaranya yakni a) Meningkatkan kualitas Sumber Daya Manusia (SDM) dimulai dari bagian ketenagakerjaan yang akan dikembangkan dengan mengadakan pelatihan khusus terkait pemanfaatan sarana SI/TI serta memberikan bantuan dana kepada pihak aparatur yang ingin melanjutkan pendidikan ke jenjang yang lebih tinggi, b) Membenahi perangkat SI/TI yang belum memadai atau perlu untuk dibangun secara khusus, diantaranya website mengenai pengenalan, promosi serta profil dinas yang masih terpusat dan dikelola oleh pemerintah pusat, sehingga banyak informasi yang tidak terupdate secara berkala. Melalui hal tersebut maka perlu ada pembangunan website khusus dinas. Selain itu beberapa aplikasi lainnya seperti EPPROC ESDM, SILUP ESDM, website umum penambangan per-kabupaten serta sistem absensi dengan scan sidik jari yang harus selalu diperbaharui dan dikelola datadata yang ada sehingga selalu terupdate. c) Membangun program kerja baru terkait eksplorasi dalam bidang ESDM, d) Membangun tim kerja untuk merencanakan pembangunan macam piranti SI/TI yang dapat membantu meningkatkan kinerja operasional dan fungsional. e) Perlu ada peningkatan keamanan dalam bidang SI/TI seperti dalam proses backup data serta pemeliharaan secara rutin.

2) Identifikasi Strategis Manajemen SI/TI: Usulan strategis selanjutnya didapatkan melalui identifikasi strategis manajemen SI/TI pada Dinas Pertambangan dan Energi Provinsi NTT yang dilihat dari belum adanya tim khusus penanganan sarana prasarana SI/TI pada dinas maka strategi yang perlu ada yaitu harus direncanakannya penyusunan tim kerja untuk pembangunan serta pengembangan SI/TI pada Dinas Pertambangan dan Energi Provinsi NTT serta meningkatkan pengawasan dalam pengelolaan ESDM dengan merancang penjadwalan yang jelas dan terarah.

3) Identifikasi Strategis TI: Dilihat dari pentingnya pembenahan piranti SI/TI dalam mendukung kemajuan dinas maka strategis IT yang perlu dijalankan yaitu dalam hal pemeliharaan serta peningkatan sarana prasarana IT yang lebih beragam.

E. Roadmap Portofolio Aplikasi

Berdasarkan hasil analisis yang telah dilakukan maka dapat disusunkan usulan roadmap portofolio sesuai kebutuhan dinas yang ditampilkan berikut ini:

TABEL IVV

PEMETAAN ROADMAP PORTOFOLIO SI/TI

\begin{tabular}{|l|c|l|l|}
\hline No. & Pengguna & \multicolumn{1}{|c|}{$\begin{array}{c}\text { SI/TI Saat } \\
\text { Ini }\end{array}$} & $\begin{array}{c}\text { SI/TI Solusi } \\
\text { Usulan }\end{array}$ \\
\hline & Subbag & - SIMPEG & - E-Surat (Sistem \\
1. & $\begin{array}{c}\text { Umum \& } \\
\text { Kepegawaian }\end{array}$ & $\begin{array}{l}\text { (Sistem } \\
\text { Pengelolaan }\end{array}$ & $\begin{array}{c}\text { masuk dan surat } \\
\text { keluar, proposal }\end{array}$ \\
\hline
\end{tabular}

\begin{tabular}{|c|c|c|c|}
\hline & & $\begin{array}{l}\text { SDM \& data } \\
\text { pegawai) }\end{array}$ & $\begin{array}{l}\text { masuk dan keluar } \\
\text { pada dinas) } \\
\text {-Website Dinas } \\
\text { ESDM NTT }\end{array}$ \\
\hline 2. & $\begin{array}{c}\text { Subbag } \\
\text { Administrasi } \\
\text { \& Keuangan }\end{array}$ & $\begin{array}{l}\text { - SIKEU } \\
\text { ESDM } \\
\text { (Sistem } \\
\text { Pengelolaan } \\
\text { Administrasi } \\
\text { \& Keuangan) }\end{array}$ & $\begin{array}{l}\text { - SI-ARSIP } \\
\text { (Sistem } \\
\text { pengarsipan) }\end{array}$ \\
\hline 3. & $\begin{array}{c}\text { Subbag Tata } \\
\text { Usaha }\end{array}$ & $\begin{array}{l}\text { - EPROC } \\
\text { ESDM } \\
\text { (Sistem } \\
\text { Pengadaan } \\
\text { Sarana } \\
\text { Prasarana) }\end{array}$ & $\begin{array}{c}\text { - SI-Relation } \\
\text { integrasi dengan } \\
\text { EPROC ESDM } \\
\text { (Sistem } \\
\text { pengelolaan } \\
\text { stakeholder) } \\
\text { - SI-JAMU } \\
\text { (Sistem Penjamin } \\
\text { Mutu) }\end{array}$ \\
\hline 4. & $\begin{array}{l}\text { Subbag } \\
\text { Program }\end{array}$ & $\begin{array}{l}\text { - SI ESDM } \\
\text { (Sistem } \\
\text { Informasi } \\
\text { Pengawasan } \\
\text { dan } \\
\text { Penjadwalan } \\
\text { Distribusi } \\
\text { ESDM) }\end{array}$ & $\begin{array}{c}\text {-SI-Facility } \\
\text { (Sistem } \\
\text { Informasi } \\
\text { Pengelolaan, } \\
\text { pengembangan } \\
\text { Fasilitas SI/TI) }\end{array}$ \\
\hline 5. & $\begin{array}{c}\text { Pegawai } \\
\text { Dinas ESDM }\end{array}$ & $\begin{array}{l}\text { - Sistem } \\
\text { absensi } \\
\text { Fingerprint } \\
\text { Biometrik }\end{array}$ & $\begin{array}{c}\text { - SI Terintegrasi } \\
\text { (Sistem yang } \\
\text { mengintegrasikan } \\
\text { kegiatan } \\
\text { operasional dan } \\
\text { fungsional pada } \\
\text { setiap bidang) }\end{array}$ \\
\hline 6. & $\begin{array}{l}\text { Pengusaha } \\
\text { ESDM }\end{array}$ & $\begin{array}{l}\text { - SILUP } \\
\text { ESDM } \\
\text { (Sistem } \\
\text { Pengelolaan } \\
\text { Pelaporan } \\
\text { Hasil Usaha } \\
\text { Tambang) }\end{array}$ & $\begin{array}{c}\text { - SI-Perizinan } \\
\text { diintegrasikan } \\
\text { dengan SILUP } \\
\text { (Sistem layanan } \\
\text { perizinan usaha } \\
\text { bidang ESDM } \\
\text { online) } \\
\text {-SMS Gateway }\end{array}$ \\
\hline 7. & Pusat & $\begin{array}{l}\text { - Website } \\
\text { umum dinas } \\
\text { - Modul } \\
\text { Verifikasi } \\
\text { Penjualan } \\
\text { (MVP) }\end{array}$ & $\begin{array}{l}\text { - SI Kinerja } \\
\text { (Sistem } \\
\text { Pelaporan kinerja } \\
\text { dinas pada } \\
\text { berbagai wilayah }\end{array}$ \\
\hline
\end{tabular}

Dari hasil roadmap portofolio dapat dipetakan perencanaan jangka waktu implementasi dari rencana strategis SI/TI yang terbagi selama kurun waktu 5 tahun ke depan. Perinciannya sebagai berikut:

TABEL V

JADWAL IMPLEMENTASI PORTOFOLIO SI/TI

\begin{tabular}{|l|l|l|l|l|l|}
\hline \multicolumn{1}{|c|}{ Solusi SI/TI } & $\mathbf{2 0 2 1}$ & $\mathbf{2 0 2 2}$ & $\mathbf{2 0 2 3}$ & $\mathbf{2 0 2 4}$ & $\mathbf{2 0 2 5}$ \\
\hline $\begin{array}{l}\text { Membenahi } \\
\text { SI/TI yang } \\
\text { belum memadai }\end{array}$ & & & & & \\
\hline E-SURAT & & & & & \\
\hline $\begin{array}{l}\text { Website Dinas } \\
\text { ESDM NTT }\end{array}$ & & & & & \\
\hline
\end{tabular}




\begin{tabular}{|l|l|l|l|l|l|}
\hline SI-ARSIP & & & & & \\
\hline SI-JAMU & & & & & \\
\hline SI-FACILITY & & & & & \\
\hline SI-INTEGRASI & & & & & \\
\hline SI- KINERJA & & & & & \\
\hline
\end{tabular}

\section{KESIMPULAN DAN SARAN}

Berdasarkan penelitian yang dilakukan maka dapat diambil kesimpulan akhir yaitu melalui penelitian analisa rancangan strategis SI/TI pada Dinas Pertambangan dan Energi Provinsi NTT menggunakan Framework Ward and Peppard mampu diketahui beragam permasalahan nyata yang tengah dihadapi pihak instansi, dan berhasil dipetakan sebanyak 4 piranti SI/TI yang harus diperbaharui serta 8 aplikasi usulan yang harus dibangun guna mendukung tujuan serta visi dan misi dinas. Perencanaan strategis SI/TI yang telah dilakukan menghasilkan rekomendasi portofolio sesuai dengan kebutuhan dan kondisi terkini pada Dinas Pertambangan dan Energi Provinsi NTT. Portofolio ini akan menjadi usulan yang selanjutnya diimplementasikan oleh dinas dengan jangka waktu rencana kerja selama 5 tahun ke depan.

Beberapa saran untuk penelitian selanjutnya a) Perencanaan strategis sistem informasi dan teknologi informasi ini dapat diimplementasikan dan diuji lebih lanjut untuk meningkatkan kinerja operasional dan fungsional dinas dalam mendukung keunggulan kompetitif, b) Perencanaan strategis sistem informasi dan teknologi informasi ini dapat dikembangkan lebih lanjut dengan memanfaatkan model analisis atau framework lainnya yang belum digunakan, c) Perencanaan strategis sistem informasi dan teknologi informasi belum meliputi seluruh aspek, karena hanya melihat kinerja organisasi yang lebih berfokus pada bidang industri, ketenagakerjaan serta hubungan publik pada dinas. Untuk penelitian berikutnya dapat berfokus pada keseluruhannya sehingga dapat memberikan saran yang lebih lengkap.

\section{REFERENSI}

[1] Tavares, O. M. I., Analisis dan Perancangan Layanan Aspirasi dan Informasi Pada Kelurahan Oebufu, Jurnal Teknologi Terpadu: 5(2), pp. 226, 2019.

[2] Romindo, R., Niar, H., Sipayung, R., Julyanthry, J., Yendrianof, D., Pelu, M. F. A., dan Purba, B., Sistem Informasi Bisnis, Edisi 1, 2020, Yayasan Kita Menulis.

[3] Larasati, P. S., Evaluasi Strategi Dalam Menghadapi Persaingan Bisnis (Studi Kasus Pada PT. Telekomunikasi Indonesia, Tbk), Doctoral dissertation, Yogyakarta, Indonesia: Universitas Islam Indonesia, 2019.

[4] F. A. Winata, M. Miyasto, dan Y. Sugiarto, Pengaruh Kualitas Hubungan dan Kemampuan Adaptasi Terhadap Lingkungan yang Mempengaruhi Keunggulan Bersaing dan Implikasinya pada Kinerja Perusahaan (Studi pada PT. Aga
Pratama), Doctoral Dissertation. Semarang, Indonesia: Diponegoro University, 2016.

[5] Widiati, I. Sholihah, U. Ema, dan Henderi, Perencanaan Strategis Sistem Informasi untuk Meningkatkan Keunggulan Kompetitif Sekolah Islam Terpadu. Creative Information Technology Journal: Vol 2.4: pp 329-340. 2015.

[6] Arianto, M. F. R., Implementasi Pasal 86 Undang-Undang Nomor 5 Tahun 2014 Tentang Aparatur Sipil Negara Pada Kedisiplinan Pegawai Kantor Kecamatan Gunungpati Kota Semarang, Doctoral dissertation, Semarang, Indonesia: Universitas Negeri Semarang, 2018.

[7] Irawan, Y., Perencanaan Strategis SI/TI dengan Menggunakan Framework Ward And Peppard di STIKES Hang Tuah Pekanbaru. Jurnal Ilmu Komputer: 6(1), pp 25-32, 2017.

[8] Krisnanto, D. M., Perencanaan Strategis Sistem Informasi Untuk Meningkatkan Keunggulan Kompetitif dengan Metode Ward and Peppard Pada SMA Fons Vitae, Skripsi, Jakarta, Indonesia: Institut Bisnis dan Informatika Kwik Kian Gie, Jakarta, 2019.

[9] Prasetyo, D. E., Wijaya, A F., Perencanaan Strategis SI/TI menggunakan Framework Ward and Peppard (Studi Kasus: PO. Blue Star). InComTech: Jurnal Telekomunikasi dan Komputer, 10(3), pp 177-188, 2020.

[10] D. Fitrawan, Analisis Perencanaan Strategis Di Dinas Energi dan Sumber Daya Mineral (ESDM) Kabupaten Kuantan Singingi. Jurnal Ilmu Administrasi: Vol 1.2. 2015.

[11] W. A. Sudrajat, Penerapan Framework Zachman Dalam Perancangan Arsitektur Sistem Manajemen Penyusunan Anggaran Keuangan Daerah (Studi Kasus UPTD Graha Teknologi Sriwijaya). Creative Information Technology Journal, 6 (1), pp 51-63. 2015.

[12] M. S. Riani, Penerapan Zachman Framework pada Arsitektur Sistem Penggajian (Studi Kasus: PT. Anugerah Mitra Mulia). Jurnal Riset Sistem Informasi dan Teknologi Informasi, 2 (1), pp 19-32. 2020.

[13] Kasma, U., Perencanaan Strategis Sistem Informasi Untuk Meningkatkan Persaingan Kompetitif. CSRID (Computer Science Research and Its Development Journal), 11(3), pp 149-157, 2021.

[14] A. Azis, T. Darmizal, Perencanaan Strategis Sistem Informasi dan Teknologi Informasi di Dinas Pendapatan, Pengelolaan Keuangan dan Aset Kabupaten Kampar (Model Strategis Ward dan Peppard). Jurnal CoreIT, Vol 2.2. 2016.

[15] Fitrah, Muh., Metodologi penelitian: penelitian kualitatif, tindakan kelas dan studi kasus, 2018, CV Jejak (Jejak Publisher).

[16] Ikhwan, A., dan Brajannoto, D., Analisis Perencanaan Strategis Sistem Informasi dan Teknologi Informasi Menggunakan Framework Ward dan Peppard. Jurnal Teknologi dan Informatika (JEDA), 1(1), pp 1-12, 2020.

[17] Meftahudin, M., Putranto, A., dan Wijayanti, R., Penerapan Analisis SWOT dan Five Forces Porter Sebagai Landasan untuk Merumuskan Strategi Pemasaran dalam Meningkatkan Laba Perusahaan (Studi Pada Tin Panda Collection di Kabupaten Magelang). Journal of Economic, Management, Accounting and Technology (JEMATech), 1(1), pp 22-30, 2018.

[18] Kristanto, T., Perencanaan Strategis Sistem Informasi dan Teknologi Informasi Pada PT Adira Dinamika Multi Finance, Seminar Nasional Sistem Informasi Indonesia (SESINDO), pp 1-7, 2015

[19] Hardjanto, K., Perencanaan Strategis Sistem Informasi Dinas Pertanian, Peternakan dan Perikanan Kota Magelang Dengan Metode Ward dan Peppard. Jurnal Teknologi Informasi dan komunikasi, 4(2), pp 88-99, 2016.

[20] Putri, C. P. N., TA: Perencanaan Strategis Sistem dan Teknologi Informasi pada RSIA Putri Surabaya Berdasarkan Metode Ward and Peppard, Doctoral dissertation, Surabaya, Indonesia: Institut Bisnis dan Informatika STIKOM Surabaya, 2018.

[21] Firmansyah, Y., dan Purwaningtias, D., Analisa Metodologi Ward \& Peppard Dalam Penentuan Perencanaan Strategis SI/TI. CYBERNETICS, 1(02), pp 70-82, 2017. 